\section{Discussion}

It seems from this study that mothers who smoke in pregnancy are less likely to choose to breast feed their babies. This may reflect the personality of a woman who has continued to smoke despite repeated antenatal advice to the contrary.

Considering only the mothers who wished to breast feed, there appears to be a relationship between smoking and failure to maintain breast feeding for 6 weeks. This relationship is more pronounced in the heavier smokers and is also seen within each socioeconomic group.

It appears, therefore, that independent of socioeconomic group, a woman who wants to breast feed will be more successful if she does not smoke. Support for this finding is reported in animal experiments which show that nicotine can reduce milk production. ${ }^{5}$ Nicotine is also excreted in breast milk ${ }^{6}$ but its effects on the newborn baby are not reported. It may be the cause of increased fretfulness which is interpreted as an unsettled baby due to underfeeding. The problem resolves when bottle feeding starts.

An inadequate milk supply and an unsettled baby are common reasons given for stopping breast feeding. ${ }^{7}$ In this study more of the smoking than the non-smoking mothers gave these as the reasons for changing to bottle feeds, but the difference was not statistically significant. More detailed investigation into the effect of smoking on lactation and infant behaviour are needed.

I thank Dr R O Walters, consultant paediatrician, for encouragement and advice, and the health visitors, Aldershot Area, for help in the collection of the data.

\section{References}

1 Butler N R, Goldstein H, Ross E M. Cigarette smoking in pregnancy: its influence on birth weight and perinatal mortality. Br Med J 1972; ii: 127-30.

2 D'Souza S W, Black P, Richards B. Smoking in pregnancy: association with skinfold thickness, maternal weight gain, and fetal size at birth. $\mathrm{Br} M e d J 1981 ; 282$ : 1661-3.

3 Whichelow M J. Breast feeding in Cambridge, England: factors affecting the mother's milk supply. J Adv Nursing $1979 ; 4: 253-61$.

4 Underwood P, Hester L L, Laffitte T, Jr, Gregg K V. The relationship of smoking to the outcome of pregnancy. Am J Obstet Gynecol 1965; 91 : 270-6.

5 Terkel J, Blake C A, Hoover V, Sawyer C H. Pup survival and prolactin levels in nicotine treated lactating rats. Proc Soc Exp Biol Med 1973; 143: 1131-5.

6 Ferguson B B, Wilson D J, Schaffner W. Determination of nicotine concentrations in human milk. Am J Dis Child 1976; 130: 837-9.

7 Starling J, Fergusson D M, Horwood L V, Taylor B. Breast feeding success and failure. Aust Paediatr J 1979; 15: $271-4$.

Correspondence to $\operatorname{Dr}$ A J Lyon, Department of Child Health, St George's Hospital, Blackshaw Road, London SW17 OQT.

Received 14 December 1982

\title{
Testicular feminisation syndrome presenting in the newborn
}

\author{
M SHERIDAN-PEREIRA AND NIALL O'BRIEN \\ Department of Paediatrics, National Maternity Hospital, Dublin
}

SUMMARY Testicular feminisation syndrome in a neonate was confirmed by cytogenetic studies. Karyotype analysis in 2 phenotypically female siblings showed the presence of the disorder in the 2 year old sibling. Subsequently a fourth phenotypically female sibling showed the disorder.

In general testicular feminisation syndrome presents in women because of primary amenorrhoea, or coincidentally at laparotomy, or as unilateral or bilateral inguinal masses that are male genital ducts and testes in a hernial sac. Inguinal hernia in prepubertal girls as an initial clinical sign of testicular feminisation syndrome is surprisingly rare. In a retrospective study ${ }^{1}$ on prepubertal girls $2.0 \%$ only of inguinal hernias were associated with the syndrome and none was found in a prospective study. ${ }^{2}$

In 1962 Gans and Rubin ${ }^{1}$ described the syndrome in a 13 day old infant with symptoms and signs of an incarcerated right inguinal hernia. In the absence of symptoms or family history, however, recognition in the newborn has not been previously described. Affected individuals generally appear normal at birth and throughout childhood. Identification of the syndrome among other family members is common.

\section{Case report}

In 1977 a phenotypically female infant weighing $3080 \mathrm{~g}$ at birth was noted on routine physical examination to have bilateral inguinal masses. A buccal 
smear was chromatin negative. Chromosomal studies showed a normal autosomal complement with an XY sex chromosome constitution (46 XY male). Karyotype analysis was then undertaken on the 2 phenotypically female siblings aged 2 and 6 years and this showed the disorder in the younger (46 XY male).

In 1980 another phenotypically female sibling was born and the karyotype was again $46 \mathrm{XY}$ male though no abnormalities were detected on routine physical examination.

\section{Discussion}

The descriptive term testicular feminisation was suggested in 1953 by Morris ${ }^{3}$ to designate a subgroup of patients with male pseudohermaphroditism who had in common certain clinical features. Patients with testicular feminisation syndrome are phenotypic females with an entirely female psychosexual orientation, despite a $46 \mathrm{XY}$ karyotype.

The clinical manifestations are attributed to complete androgen insensitivity coupled with testicular secretion of oestrogens or their precursors. Two variants are described. ${ }^{4}$ In the first variant, intracellular androgen binding is reduced or absent due either to absence of a structurally normal androgen-binding protein or the presence of an altered receptor protein. ${ }^{5}$ In the second variant, androgen binding is normal ${ }^{4}$ but there are qualitative differences in the androgen receptor, or anomalies of the post receptor effector mechanism for androgen action. $^{6}$

Though the exact genetic mechanisms have not been ascertained, the distribution of affected patients in families indicates that the mode of inheritance is $X$ linked recessive or sex modified autosomal dominant ${ }^{7}$ transmitted by the maternal carrier. The $\mathrm{X}$ linked gene specifying for the androgen receptor presumably controls either the synthesis or the structure of the receptor protein..$^{5}$ Inheritance as an $\mathrm{X}$ linked recessive is the most widely accepted view as it best explains the ratio of 2 normal females to 1 normal male to one with the syndrome which was found in hereditary studies in families of typical cases and in Morris's original series in 1953. The carriers or heterozygotes are normal fertile women who may have delayed sexual maturation. ${ }^{8}$ The mother of these children had normal sexual hair and her menarche had occurred at 13 years.

Recognition of the syndrome in infancy or early childhood raises important questions for clinical management and genetic counselling. Doubt and anxiety regarding sex and development may be created, and thus affect adversely the psychosexual orientation of the child. To avert serious emotional problems of this nature information in relation to the male chromosomal constitution may be undesirable.

Counselling in this family was initiated by the paediatrician and subsequently by the endocrinologist and genetic counsellor. Reassurance was given in relation to normal growth and normality of other parameters of development as females. Since the inheritance is $\mathrm{X}$ linked recessive or sex modified autosomal dominant $50 \%$ of sons will be affected and reared as girls and $50 \%$ of daughters are carriers with the same reproductive genetic prognosis as their mothers. In view of this the recognised recurrence risk is $25 \%$ for future pregnancies. The $\mathrm{XX}$ sibling is a possible carrier but no test has been developed to permit diagnosis of the carrier state.

Strong evidence has accumulated that the testes in these individuals possess increased cancer potential ${ }^{3}$; this is the principal reason for gonadectomy. Therefore, if the diagnosis is made after puberty gonadectomy is performed immediately. There is some disagreement, however, about the timing of gonadectomy in patients diagnosed before puberty. The hazards of malignancy, incomplete masculinisation at puberty (if it is the incomplete variant), or psychological trauma related to the adolescent's knowledge of the gonadectomy must be weighed against the need for oestrogen treatment to feminise if the testes are removed before puberty. However, oestrogen therapy is generally initiated if gonadectomy is undertaken after puberty to prevent menopausal symptoms.

\section{References}

1 Gans S L, Rubin C L. Apparent female infants with hernias and testes. Am J Dis Child 1962; 104: 82-6.

2 German J, Simpson J L, Morillo-Cucci G, Passarge E, De Mayo A P. Letter: Testicular feminisation and inguinal hernia. Lancet $1973 ; 1$ : 891.

3 Morris J McL. The syndrome of testicular feminization in male pseudo hermaphrodites. Am J Obstet Gynecol $1953 ; 65$ : 1192-211.

4 Amrhein J A, Meyer W J, Jones H W, Migeon C J. Androgen insensitivity in man: evidence for genetic heterogeneity. Proc Natl Acad Sci USA 1976; 73: 891-4.

5 Keenan B S, Meyer W J, Hadjian A J, Jones H W, Migeon C J. Syndrome of androgen insensitivity in man: absence of 5 -dihydrotestosterone binding protein in skin fibroblasts. J Clin Endocrinol Metab 1974; 38: 1143-6.

- Brown T R, Maes M, Rothwell S W, Migeon C J. Human complete androgen insensitivity with normal dihydrotesterone receptor binding capacity in cultured genital skin fibroblasts: evidence for a qualitative abnormality of the receptor. J Clin Endocrinol Metab 1982; 55: 61-9.

7 Grumbach M M, Barr M L. Cytological tests of chromosomal sex in relation to sexual anomalies in man. Recent Prog Horm Res 1958; 14: 255-334.

8 Mishell D R. Familial intersexuality: report of three unusual cases. Am J Obstet Gynecol 1938; 35: 960-70.

Correspondence to $\operatorname{Dr} M$ Sheridan-Pereira, National Maternity Hospital, Holles Street, Dublin 2, Ireland.

Received 14 December 1982 